\title{
Researches on the influence of the slags formed in the installations on the hydrogen removal efficiency $\left.{ }^{\circ}\right)$
}

\author{
F. Drăgoi*, A. Socalici*, E. Ardelean*, E. Popa* and T. Heput*
}

\begin{abstract}
Modern technology requires ever more high-quality steel and special steels, with properties corresponding to very different purposes. Because of the interdependence of the factors that determine the overall quality of the steel and those who determine the gas content, this is an issue of growing importance for the development, treatment and casting of steel. Slag plays an important part in the development phase no matter the process phase is. The influence of synthetic slags during LF treatment facility is examined based on the degree of removal of hydrogen. After processing the experimental data there has been established the optimal basicity variation on which one can determine the chemical composition of slag $\left(\mathrm{CaO}, \mathrm{SiO}_{2}, \mathrm{Al}_{2} \mathrm{O}_{3}, \mathrm{MgO}\right)$ for the secondary treatment of steel.
\end{abstract}

\section{Investigaciones sobre la influencia de la escoria sobre el rendimiento de eliminación del hidrógeno}

\begin{abstract}
Resumen
La técnica moderna necesita cada vez más acero de calidad superior y aceros especiales, con propiedades adecuadas a unos propósitos muy amplios. Gracias a la interdependecia entre los factores que determinan el contenido de gases esta constituye un problema cada vez más importante para la elaboración, tratamiento y fundición de los aceros. Una gran importancia en el proceso de elaboración le corresponde a la escoria independientemente de la fase del proceso. Se analiza la influencia de la escoria sintética durante el tratamiento en la instalación LF sobre el grado de eliminación del hidrogeno. Después de procesar los datos experimentales se establecieron los campos óptimos de variación de la basicidad en base a la cual se puede determinar la composición química de la escoria $\left(\mathrm{CaO}, \mathrm{SiO}_{2}, \mathrm{Al}_{2} \mathrm{O}_{3}, \mathrm{MgO}\right)$ para el tratamiento secundario del acero.
\end{abstract}

Palabras clave

Escoria; Hidrógeno; Acero; Solidificación; Rendimiento.

\section{INTRODUCTION}

The properties of a steel depend mostly on a series of agents, including the chemical composition of the steel, nature, mold, distribution and quantity of the non metallic inclusions, gas content, cast temperature, cast speed, degree of plastic deformation and the thermal treatment applied $^{[1]}$.

In the case of the semi-finished from steel, one of the causes that leads to worsening their quality is because of the hydrogen content. This can be found in steel in an atomic, molecular and other simple combinations state. Having the atomic radius smaller than the steel one, it ranks interstitially and creates a solid solution with the mass basis. It doesn't make chemical combinations with the iron or other elements that are dissolved into steel. In a molecular state it locates itself in pockets and microcavities contributing to their formation. The hydrogen quantity that is dissolved in steel depends on a series of agents, some of them being ${ }^{[2-4]}$ the temperature of the steel, work pressure in the oven and in liquid steel treatment installation, chemical composition of the steel, elaboration and casting procedure etc.

Practically, during the usual elaboration, the hydrogen content of steel frequently varies between $1.8-10 \mathrm{ppm}$, and if the steel is the subject of the

(•) Trabajo recibido el día 14 de febrero de 2011 y aceptado en su forma final el día 8 de marzo de 2011.

* University "Politehnica", Timisoara, Faculty of Engineering, Henudoara, Revolutiei, 5 , 331128, Hunedoara, Romania. 
secondary treatment and vacuum casting metallurgy, the content of hydrogen is of maximum $1.8-2.2 \mathrm{ppm}$, (for instance at reciculatory treatment the content of hydrogen is reduced to $1.5 \mathrm{ppm}$ and for a steel in a vacuum induction oven or in vacuum arc remelting the content of hydrogen is $1 \mathrm{ppm}$ at its highest ${ }^{[3]}$.

The main sources from which the hydrogen can turn into steel in liquid condition are: the metallic load and all the other materials used in the elaboration and casting, refractory materials, cooled elements of the oven and of installations for the treatment of liquid steel, humidity of the atmosphere in which one works, etc. The content of hydrogen must be limited in steel because it has negative effects on the semi-finished or on the finished products. In a liquid state, the steel can dissolve great quantities of hydrogen which in the solidification process dissociate in the solution and in certain phases of metal processing some imperfections can appear, such as: pockets, shadow lines and flakes. For instance, in a steel with a high content of hydrogen, if it also contains nitrogen, pockets can appear at a depth of $20-30 \mathrm{~mm}$ under the exterior crust of the ingot which open themselves in the forging process, causing the appearance of the splits on the surface of the product ${ }^{[5]}$.

The influence of the hydrogen on the quality of the steels can be synthetised in: making porosities (pockets), producing flake type discontinuities (microscopical), embrittlement of the base mass and reduction of the physico-mechanical characteristics and electrical properties, cold deformations, weldability, etc.

The flakes appear mostly in steels with a high level of hydrogen and in the situations of dehydrogenation treatment failure and they are placed in some areas which have a lower resistance, determined by the presence of the non-metallic inclusions, of the gliding lines, the limits of the grains, chemical segregations, tensions caused by deformations or cooling with high speed of the forging ${ }^{[6]}$. Through an appropriate preliminary thermic treatment and slow cooling there can be reductions of the downgrading or rejecting of the steel products with sensitivity in the appearance of the flakes.

\section{EXPERIMENTAL}

In this paper it is analized the influence of the characteristics of the slag in the removal efficiency of the hydrogen in steel during its secondary treatment in the LF installation. The influence of the slag chemical composition is analized according to the basicity parameter $\left(\mathrm{I}_{\mathrm{b}}\right)$ expressed according to the following equations:

$$
\begin{gathered}
I_{b 1}=\frac{(\mathrm{CaO})}{\left(\mathrm{SiO}_{2}\right)} \\
I_{b 2}=\frac{(\mathrm{CaO})+(\mathrm{MgO})}{\left(\mathrm{SiO}_{2}\right)} \\
I_{b 3}=\frac{(\mathrm{CaO})+(\mathrm{MgO})}{\left(\mathrm{SiO}_{2}\right)+\left(\mathrm{Al}_{2} \mathrm{O}_{3}\right)}
\end{gathered}
$$

The industrial experimentations regarding the influence of the slag characteristics on the hydrogen removal efficiency were performed on a technological flow of processing the steel made of an electric arc furnace, EBT type of $100 \mathrm{t}$ capacity, LF installation and continuous cast installation with 5 wires.

At the secondary treatment of the steel in the LF installation the argon bubbling of the metallic bath takes place and also the addition for correcting the chemical composition and for deoxidation and desulphuration as well as the additions for reducing slag formation (lime, bauxite). The duration of the secondary treatment of the steel is $50-70 \mathrm{~min}$, required by the timing with the continuous cast installation ${ }^{[7]}$.

Further on there are presented the results obtained during the industrial experimentations made in two technological variants:

- Variant A the lime used for slag formation was burnt;

- Variant B the lime used for slag formation was not burnt

In both variants a number of 20 charges was experimented. The determinations regarding the chemical composition of the additions for making the reducing slag (in the LF installation) as well as the content of the hydrogen in steel were performed by the steel making plant. To determine the hydrogen removal efficiency, samples of hydrogen were taken, before the insertion of the steel ladle in the LF installation and at the end of the treatment. Concerning the reducing slag, four samples were taken during the treatment in the LF installation:

- The first sample immediately after the insertion of the steel ladle in the LF installation; 
RESEARCHES ON THE INFLUENCE OF THE SLAGS FORMED IN THE INSTALLATIONS ON THE HYDROGEN REMOVAL EFFICIENCY INVESTIGACIONES SOBRE LA INFLUENCIA DE LA ESCORIA SOBRE EL RENDIMIENTO DE ELIMINACIÓN DEL HIDRÓGENO

- The second sample 10 min after the insertion of the steel ladle in the LF installation;

- The third sample 35 min after the insertion of the steel ladle in the LF installation;

- The fourth sample at the end of the secondary treatment.

In the performed calculations, respectively in processing the experimental data, in different programmes, referring to the composition of the slag, the average of the four determinations was used.

\section{RESULTS}

The data obtained as a consequence of the experimentations on the analyzed charges were processed in the EXCEL programme to obtain some correlation equations. The results obtained both graphically and analytically are presented in figure 1 and 2 .

To determine the optimum variation domains of the $\mathrm{I}_{\mathrm{b} 1}, \mathrm{I}_{\mathrm{b} 2}, \mathrm{I}_{\mathrm{b} 3}$ parameters, we required some values for the hydrogen removal efficiency of minimum $50 \%$ in the charges with not burnt lima additions and values of minimum $40 \%$ in the charges with calcined additions. We chose these values because $40 \%$ of the analyzed charges in the A variant had the efficiency over this number and over $50 \%$ of the analyzed charges in B variant had the efficiency over this number.

Further on there are presented the results obtained in processing the dates in MATLAB programme in the case of the multiple correlation ${ }_{\mathrm{H} 2}=\mathrm{f}\left(\mathrm{I}_{\mathrm{b} 1}, \mathrm{I}_{\mathrm{b} 2}, \mathrm{I}_{\mathrm{b} 3}\right)$, both for $\mathrm{A}$ variant and $\mathrm{B}$ variant (or for both variants).

Because we cannot graphically represent (in the four dimensions space) such a correlation, from the equation with three independent parameters, through permutations we attributed to a parameter once the medium value and thus we obtained equations with two independent parameters, equation which can be graphically represented in the three dimension space ${ }^{[8]}$. We can obtain the equation with two independent parameters directly from processing the dates, but we wanted to analytically have an equation with three independent parameters, because we considered it to be more representative.

$$
\begin{aligned}
& \text { Variant A } \\
& \eta_{\mathrm{f}-\mathrm{H}-\mathrm{A}}=(-8.0236) \cdot\left(\mathrm{CaO} / \mathrm{SiO}_{2}\right)^{2} \\
& +2.2725 \cdot\left[(\mathrm{CaO}+\mathrm{MgO}) / \mathrm{SiO}_{2}\right]^{2} \\
& +19.3186\left[(\mathrm{CaO}+\mathrm{MgO}) /\left(\mathrm{SiO}_{2}+\mathrm{Al}_{2} \mathrm{O}_{3}\right)\right]^{2} \\
& -5.0916 \cdot\left[\left(\mathrm{CaO} / \mathrm{SiO}_{2}\right)(\mathrm{CaO}+\mathrm{MgO}) / \mathrm{SiO}_{2}\right] \\
& -16.0961\left[(\mathrm{CaO}+\mathrm{MgO}) / \mathrm{SiO}_{2}\right) \cdot \\
& \text { - } \left.(\mathrm{CaO}+\mathrm{MgO}) /\left(\mathrm{SiO}_{2}+\mathrm{Al}_{2} \mathrm{O}_{3}\right)\right] \\
& -33.9616\left[(\mathrm{CaO}+\mathrm{MgO}) /\left(\mathrm{SiO}_{2}+\mathrm{Al}_{2} \mathrm{O}_{3}\right) \mathrm{CaO} / \mathrm{SiO}_{2}\right] \\
& +132.6627 \cdot\left(\mathrm{CaO} / \mathrm{SiO}_{2}\right)+25.1944 \cdot\left[(\mathrm{CaO}+\mathrm{MgO}) / \mathrm{SiO}_{2}\right] \\
& +103.2782 \cdot\left[(\mathrm{CaO}+\mathrm{MgO}) /\left(\mathrm{SiO}_{2}+\mathrm{Al}_{2} \mathrm{O}_{3}\right)\right]-301.6483
\end{aligned}
$$

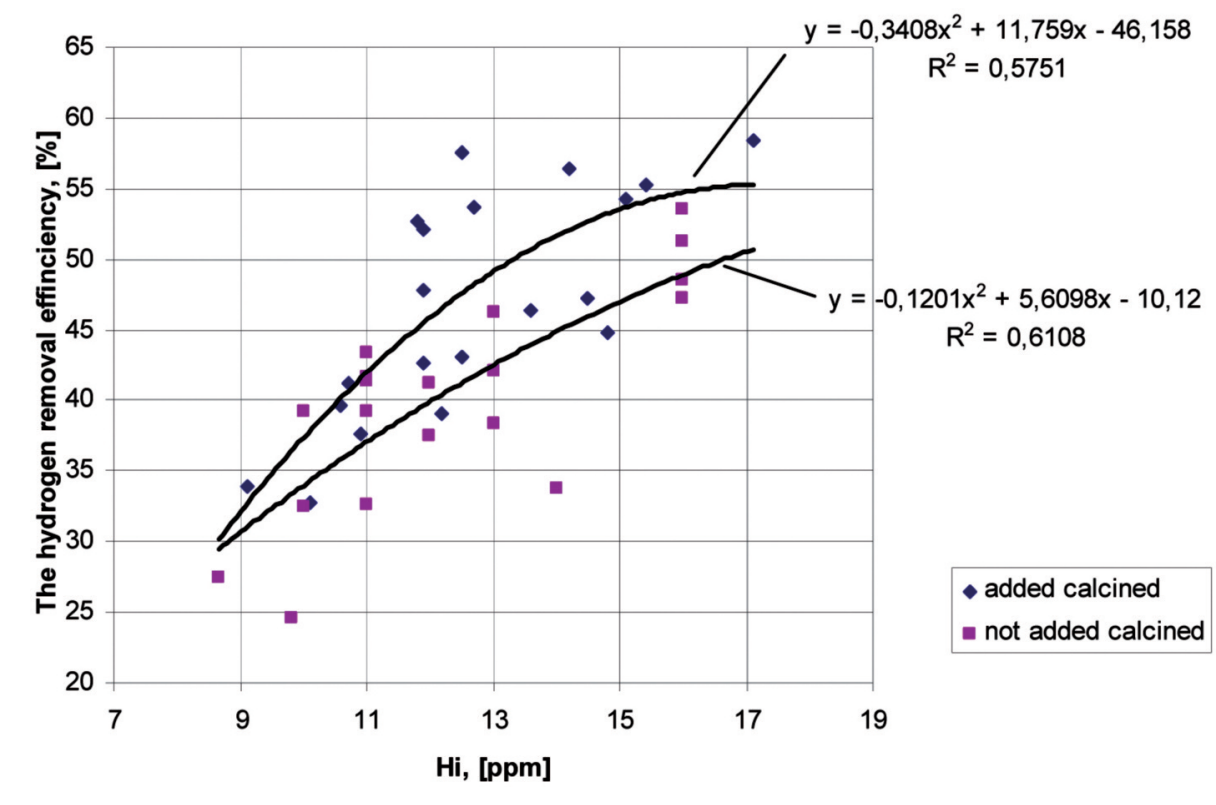

Figure 1. The variation of the hydrogen removal efficiency depending on the initial content of hydrogen.

Figura 1. Variación del rendimiento de eliminación del hidrógeno según el contenido inicial de hidrógeno. 


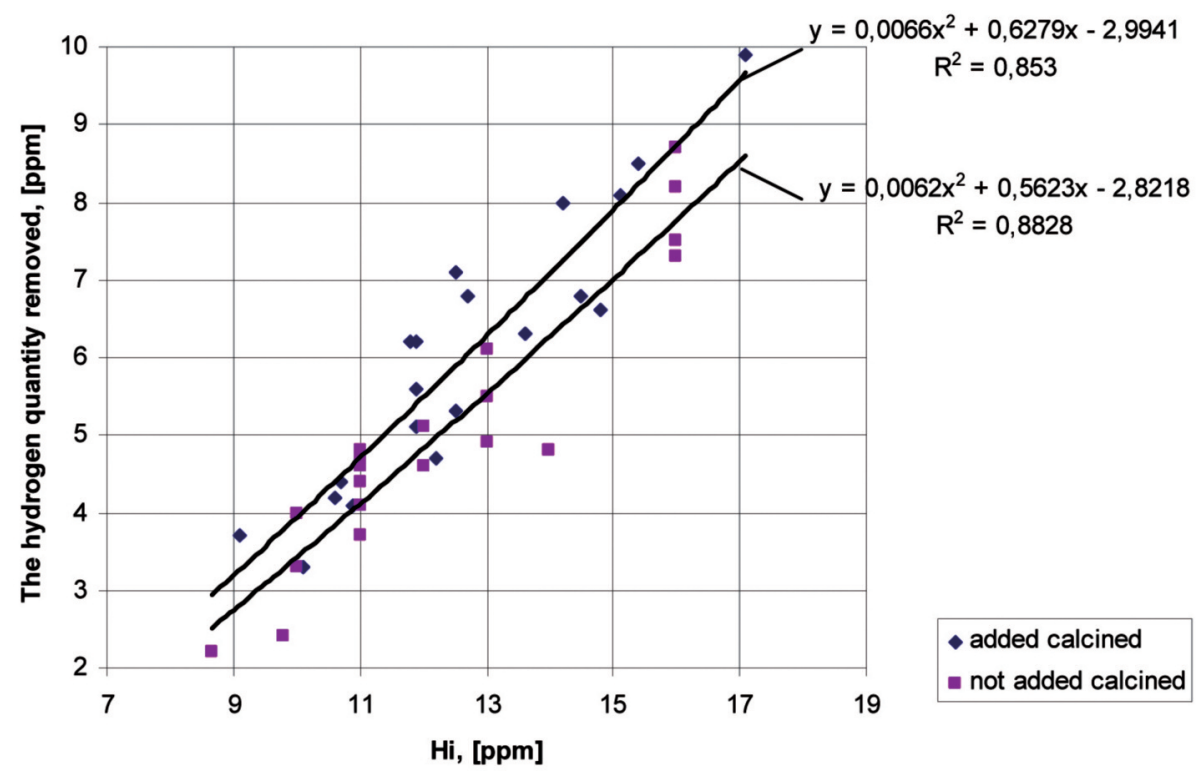

Figure 2. The variation of the hydrogen quantity removed depending on the initial content of hydrogen.

Figura 2. Variación de la cantidad de hidrógeno eliminada según el contenido inicial de hidrógeno.

Correlation coeficient $R=0.8719$

Deviation from the regression surface $S=3.7982$

Saddle point coordinations:

$$
\mathrm{CaO} / \mathrm{SiO}_{2}=3.06
$$

$(\mathrm{CaO}+\mathrm{MgO}) / \mathrm{SiO}_{2}=4.30$

$(\mathrm{CaO}+\mathrm{MgO}) /\left(\mathrm{SiO}_{2}+\mathrm{Al}_{2} \mathrm{O}_{3}\right)=1.81$

$\eta_{\mathrm{f}-\mathrm{H}-\mathrm{A}}=49.3762 \%$.

Replacing in equation (4) for $\left.\mathrm{CaO} / \mathrm{SiO}_{2}\right)=$ $\left(\mathrm{CaO} / \mathrm{SiO}_{2}\right)_{\text {med }}$ it results:

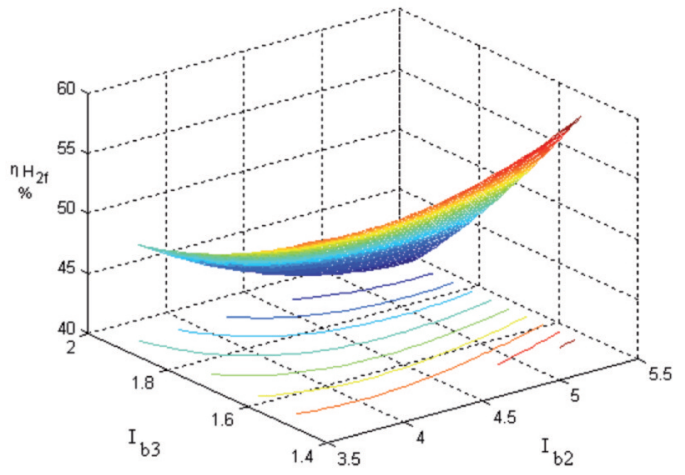

$$
\begin{aligned}
& \eta_{\mathrm{f}-\mathrm{H}-\mathrm{A}}\left(\mathrm{I}_{\mathrm{b} 1}=\mathrm{I}_{\mathrm{b} 1 \mathrm{med}}\right)=2.2725\left[(\mathrm{CaO}+\mathrm{MgO}) / \mathrm{SiO}_{2}\right]^{2} \\
&+19.3186 \cdot\left[(\mathrm{CaO}+\mathrm{MgO}) /\left(\mathrm{SiO}_{2}+\mathrm{Al}_{2} \mathrm{O}_{3}\right)\right]^{2}- \\
& 16.0961\left[\left(\mathrm{CaO}+\mathrm{MgO}^{2} / \mathrm{SiO}_{2}\right)\right. \\
&\left.\cdot(\mathrm{CaO}+\mathrm{MgO}) /\left(\mathrm{SiO}_{2}+\mathrm{Al}_{2} \mathrm{O}_{3}\right)\right] \\
&+6.2076\left[(\mathrm{CaO}+\mathrm{MgO}) / \mathrm{SiO}_{2}\right] \\
&-23.3648\left[(\mathrm{CaO}+\mathrm{MgO}) /\left(\mathrm{SiO}_{2}+\mathrm{Al}_{2} \mathrm{O}_{3}\right)\right]+81.4788
\end{aligned}
$$

The graphical representation is presented in figure 3 .

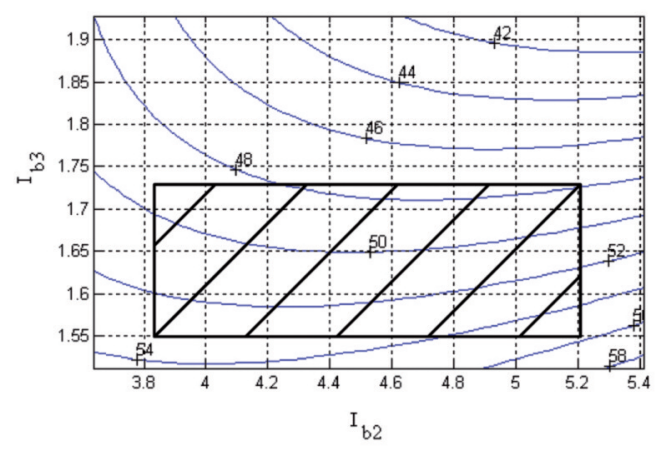

Figure 3. Hydrogen removal efficiency, variant $A, \eta_{f-H-A}$ depending on $\left(I_{b 1}\right)_{m e d}, I_{b 2}$ and $\mathrm{I}_{\mathrm{b} 3 \text {. }}$

Figura 3. Eficacia de la eficiencia del hidrógeno, la variante $A, \eta_{f-H-A}$ en función de $\left(I_{b 1}\right)_{\text {med }}, I_{b 2} y I_{b 3}$. 
RESEARCHES ON THE INFLUENCE OF THE SLAGS FORMED IN THE INSTALLATIONS ON THE HYDROGEN REMOVAL EFFICIENCY INVESTIGACIONES SOBRE LA INFLUENCIA DE LA ESCORIA SOBRE EL RENDIMIENTO DE ELIMINACIÓN DEL HIDRÓGENO

Replacing in equation (4) for $(\mathrm{CaO}+\mathrm{MgO}) / \mathrm{SiO}_{2}$ $=\left[(\mathrm{CaO}+\mathrm{MgO}) / \mathrm{SiO}_{2}\right]_{\mathrm{med}}$ it results:

$$
\begin{gathered}
\eta_{\mathrm{f}-\mathrm{H}-\mathrm{A}}\left(\mathrm{I}_{\mathrm{b} 2}=\mathrm{I}_{\cdot \mathrm{b} 2 \mathrm{med}}\right)=19.3186 \\
{\left[(\mathrm{CaO}+\mathrm{MgO}) /\left(\mathrm{SiO}_{2}+\mathrm{Al}_{2} \mathrm{O}_{3}\right)\right]^{2}+} \\
(-8.0236)\left(\mathrm{CaO} / \mathrm{SiO}_{2}\right)^{2}+(-33.9616) \\
\left.(\mathrm{CaO}+\mathrm{MgO}) /\left(\mathrm{SiO}_{2}+\mathrm{Al}_{2} \mathrm{O}_{3}\right){\left.\mathrm{CaO} / \mathrm{SiO}_{2}\right]}_{2}\right] \\
+33.9926 \cdot\left[(\mathrm{CaO}+\mathrm{MgO}) /\left(\mathrm{SiO}_{2}+\mathrm{Al}_{2} \mathrm{O}_{3}\right)\right] \\
+110.7457\left(\mathrm{CaO} / \mathrm{SiO}_{2}\right)+(-151.0923)
\end{gathered}
$$

The graphical representation is presented in figure 4.

Replacing in equation (4) $(\mathrm{CaO}+\mathrm{MgO}) /\left(\mathrm{SiO}_{2}\right.$ $\left.+\mathrm{Al}_{2} \mathrm{O}_{3}\right)=\left[(\mathrm{CaO}+\mathrm{MgO}) /\left(\mathrm{SiO}_{2}+\mathrm{Al}_{2} \mathrm{O}_{3}\right)\right]_{\text {med }}$ it results:
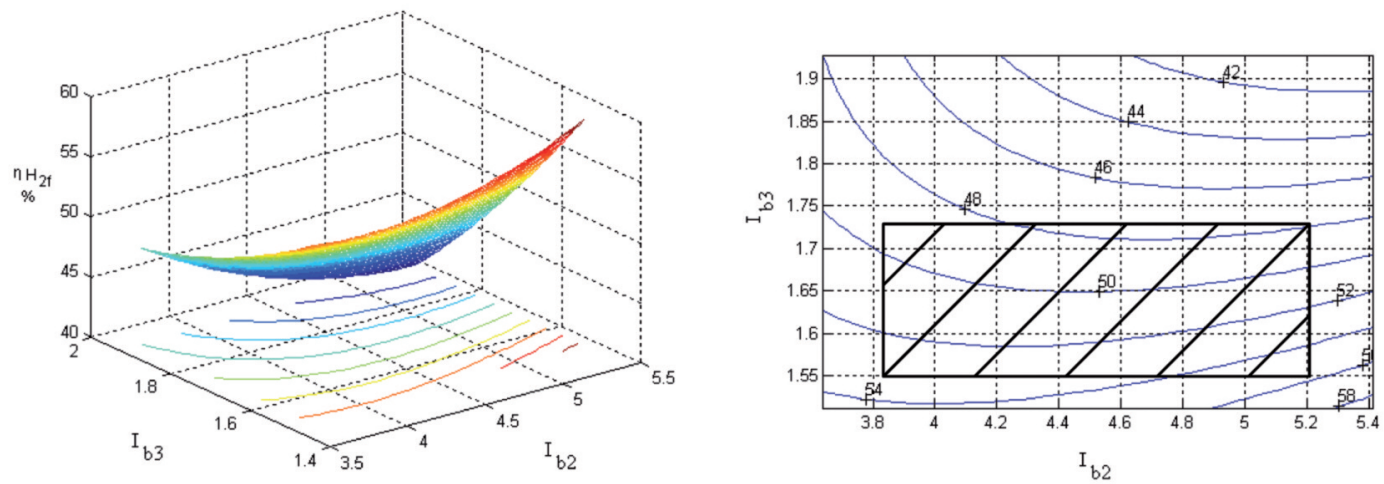

Figure 4. Hydrogen removal efficiency, variant $A, \eta_{\mathrm{f}-\mathrm{H}-\mathrm{A}}$ depending on $\left(\mathrm{I}_{\mathrm{b} 2}\right)_{\text {med }}$, $\mathrm{I}_{\mathrm{b} 1}$ and $\mathrm{I}_{\mathrm{b} 3}$

Figura 4. Eficacia de la eficiencia del hidrógeno, la variante $A, \eta_{f-H-A}$ en función de $\left(I_{b 2}\right)_{\text {med }}, I_{b 1} y I_{b 3}$
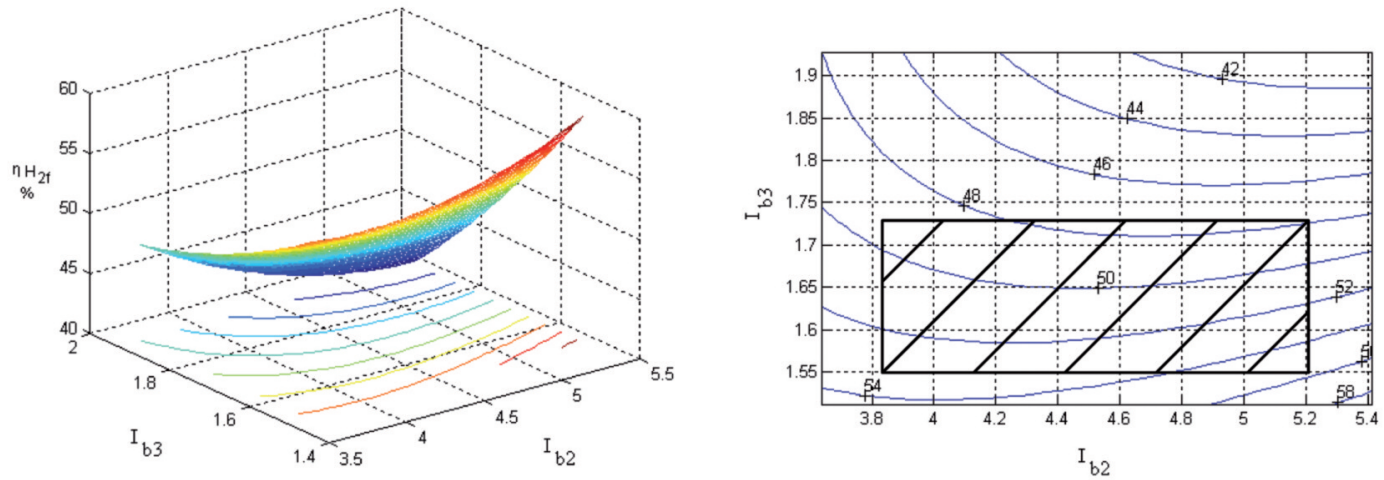

Figure 5. Hydrogen removal efficiency, variant $A, \eta_{\mathrm{f}-\mathrm{H}-\mathrm{A}}$ depending on $\left(\mathrm{I}_{\mathrm{b} 3}\right)_{\text {med }}, \mathrm{I}_{\mathrm{b} 2}$ and $\mathrm{I}_{\mathrm{b} 1}$

Figura 5. Eficacia de la eficiencia del hidrógeno, la variante $A, \eta_{f-H-A}$ en función de $\left(I_{b 3}\right)_{\text {med }}, I_{b 2} y I_{b 1}$. 


$$
\begin{aligned}
& \left.(\mathrm{CaO}+\mathrm{MgO}) /\left(\mathrm{SiO}_{2}+\mathrm{Al}_{2} \mathrm{O}_{3}\right)\right]+(-36.0268) \cdot \\
& {\left[(\mathrm{CaO}+\mathrm{MgO}) /\left(\mathrm{SiO}_{2}+\mathrm{Al}_{2} \mathrm{O}_{3}\right) \cdot \mathrm{CaO} / \mathrm{SiO}_{2}\right]} \\
& +113.4768 \cdot\left(\mathrm{CaO} / \mathrm{SiO}_{2}\right)+(-82.2804) \cdot \\
& {\left[(\mathrm{CaO}+\mathrm{MgO}) / \mathrm{SiO}_{2}\right]+38.144 \cdot} \\
& {\left[(\mathrm{CaO}+\mathrm{MgO}) /\left(\mathrm{SiO}_{2}+\mathrm{Al}_{2} \mathrm{O}_{3}\right)\right]+21.5354}
\end{aligned}
$$

Correlation coefficient $R=0.9285$

Deviation from the regression surface $S=2.6867$

Saddle point coordinations:

$$
\mathrm{CaO} / \mathrm{SiO}_{2}=2.56
$$

$(\mathrm{CaO}+\mathrm{MgO}) / \mathrm{SiO}_{2}=4.07$

$(\mathrm{CaO}+\mathrm{MgO}) /\left(\mathrm{SiO}_{2}+\mathrm{Al}_{2} \mathrm{O}_{3}\right)=1.93$

$$
\eta_{\text {f-H }-\mathrm{A}}=36.2205 \%
$$

Replacing in equation $(8)$ for $\left(\mathrm{CaO} / \mathrm{SiO}_{2}\right)=$ $\left[\left(\mathrm{CaO} / \mathrm{SiO}_{2}\right)\right]_{\text {med }}$ it results:

$$
\begin{aligned}
& \eta_{\mathrm{F}-\mathrm{H}-\mathrm{B}}\left(\mathrm{I}_{\mathrm{b} 1}=\mathrm{I}_{{ }_{\mathrm{b} 1 \mathrm{med}}}\right)=8.4303\left[(\mathrm{CaO}+\mathrm{MgO}) / \mathrm{SiO}_{2}\right]^{2} \\
& +17.0274 \cdot\left[(\mathrm{CaO}+\mathrm{MgO}) /\left(\mathrm{SiO}_{2}+\mathrm{Al}_{2} \mathrm{O}_{3}\right)\right]^{2} \\
& +(-2.8709)\left[(\mathrm{CaO}+\mathrm{MgO}) / \mathrm{SiO}_{2}\right) \\
& \left.(\mathrm{CaO}+\mathrm{MgO}) /\left(\mathrm{SiO}_{2}+\mathrm{Al}_{2} \mathrm{O}_{3}\right)\right]+(-58.8328) \\
& {\left[(\mathrm{CaO}+\mathrm{MgO}) / \mathrm{SiO}_{2}+(-75.4664)\right.} \\
& {\left[(\mathrm{CaO}+\mathrm{MgO}) /\left(\mathrm{SiO}_{2}+\mathrm{Al}_{2} \mathrm{O}_{3}\right)\right]+235.9209}
\end{aligned}
$$

The graphical representation is presented in figure 6 .

Replacing in equation (8) for $(\mathrm{CaO}+\mathrm{MgO}) /$ $\mathrm{SiO}_{2}=\left[(\mathrm{CaO}+\mathrm{MgO}) / \mathrm{SiO}_{2}\right]_{\text {med }}$ it results:

$$
\begin{gathered}
\eta_{\mathrm{f}-\mathrm{H}-\mathrm{B}}\left(\mathrm{I}_{\mathrm{b} 2}=\mathrm{I}_{\mathrm{b}_{\mathrm{b} 2 m e d}}\right)=17.0274 \cdot \\
{\left[(\mathrm{CaO}+\mathrm{MgO}) /\left(\mathrm{SiO}_{2}+\mathrm{Al}_{2} \mathrm{O}_{3}\right)\right]^{2}+} \\
(-14.4263) \cdot\left(\mathrm{CaO} / \mathrm{SiO}_{2}\right)^{2}+(-36.0268)
\end{gathered}
$$

$$
\begin{gathered}
{\left[(\mathrm{CaO}+\mathrm{MgO}) /\left(\mathrm{SiO}_{2}+\mathrm{Al}_{2} \mathrm{O}_{3}\right) \mathrm{CaO} / \mathrm{SiO}_{2}\right]} \\
+27.524 \cdot\left[\left(\mathrm{CaO}+\mathrm{MgO}_{2}\right) /\left(\mathrm{SiO}_{2}+\mathrm{Al}_{2} \mathrm{O}_{3}\right)\right] \\
+140.9804\left(\mathrm{CaO} / \mathrm{SiO}_{2}\right)-167.4708
\end{gathered}
$$

The graphical representation is presented in figure 7 .

Replacing in equation (8) $(\mathrm{CaO}+\mathrm{MgO}) /\left(\mathrm{SiO}_{2}\right.$ $\left.+\mathrm{Al}_{2} \mathrm{O}_{3}\right)=\left[(\mathrm{CaO}+\mathrm{MgO}) /\left(\mathrm{SiO}_{2}+\mathrm{Al}_{2} \mathrm{O}_{3}\right)\right]_{\text {med }}$ it results:

$$
\begin{aligned}
\eta_{\mathrm{f}-\mathrm{H}-\mathrm{B}}\left(\mathrm{I}_{\mathrm{b} 3}=\mathrm{I}_{\mathrm{b} 3 \mathrm{med}}\right)=(-14.4263) \cdot\left(\mathrm{CaO} / \mathrm{SiO}_{2}\right)^{2} \\
+8.4303 \cdot\left[(\mathrm{CaO}+\mathrm{MgO}) / \mathrm{SiO}_{2}\right]^{2} \\
+7.4354 \cdot\left[\left(\mathrm{CaO} / \mathrm{SiO}_{2}\right) \cdot\left(\mathrm{CaO}+\mathrm{MgO}^{2} / \mathrm{SiO}_{2}\right]\right. \\
+59.4366 \cdot\left(\mathrm{CaO} / \mathrm{SiO}_{2}\right)+(-86.5867) \\
\cdot\left[(\mathrm{CaO}+\mathrm{MgO}) / \mathrm{SiO}_{2}\right)+117.0631
\end{aligned}
$$

The graphical representation is presented in figure 8 .

\section{DISCUSSION}

Analyzing the dates presented in figures 1 and 2 it results that for the charges that used the burnt additions to compose the reducing slag higher values are obtained for the removed quantity of hydrogen and for the hydrogen removal efficiency as compared to the charges where the same additions were used but not calcined. In both cases there were obtained representative quadratic polynomial correlation equations. It has also been seen an increase of the removed quantity of hydrogen and of the hydrogen removal efficiency in the charges with higher content of hydrogen.
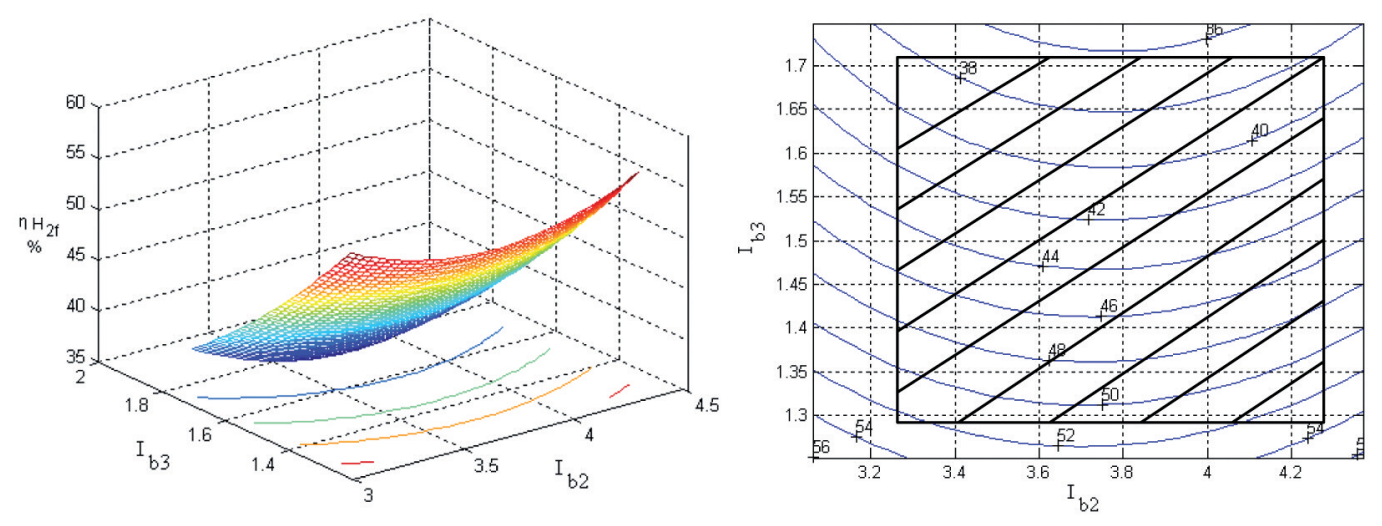

Figure 6. Hydrogen removal efficiency, variant $B, \eta_{f-H-B}$ depending on $\left(I_{b 1}\right)_{\text {med }}, I_{b 3}$ and $\mathrm{I}_{\mathrm{b} 2 \text {. }}$

Figura 6. Eficacia de la eficiencia del hidrógeno, la variante $B, \eta_{f-H-B}$ en función de $\left(I_{b 1}\right)_{m e d}, I_{b 3} y I_{b 2}$. 

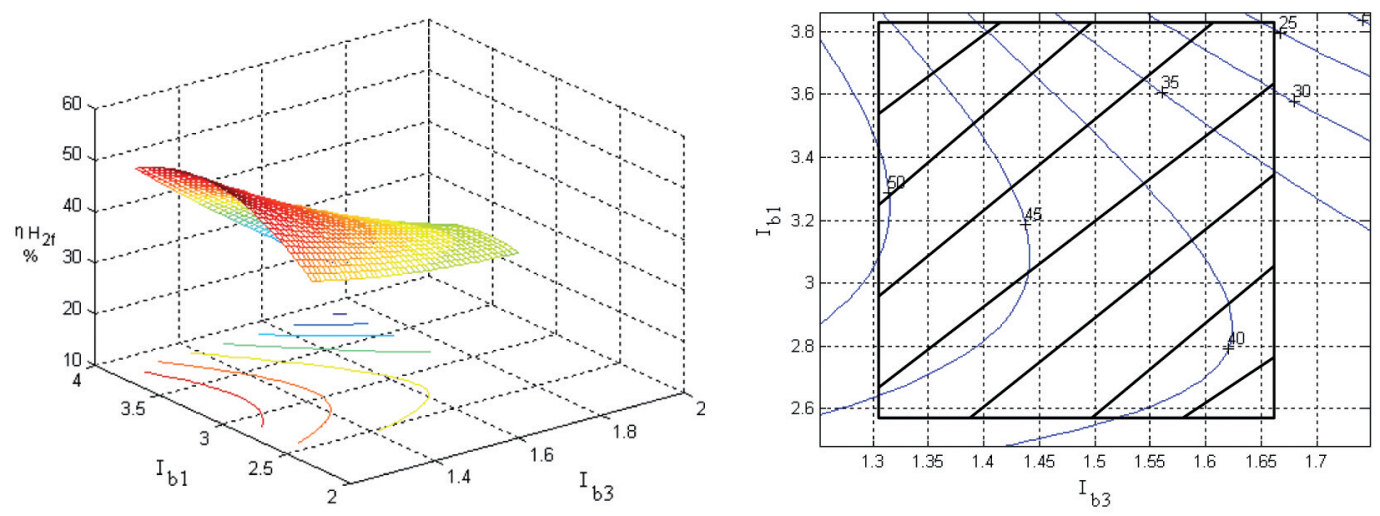

Figure 7. Hydrogen removal efficiency, variant $B, \eta_{\mathrm{f}-\mathrm{H}-\mathrm{B}}$ depending on $\left(\mathrm{I}_{\mathrm{b} 2}\right)_{\text {med }}, \mathrm{I}_{\mathrm{b} 1}$ and $\mathrm{I}_{\mathrm{b} 3}$.

Figura 7. Eficacia de la eficiencia del hidrógeno, la variante $B, \eta_{f-H-B}$ en función de $\left(I_{b 2}\right)_{\text {med }}, I_{b 1} y I_{b 3 .}$
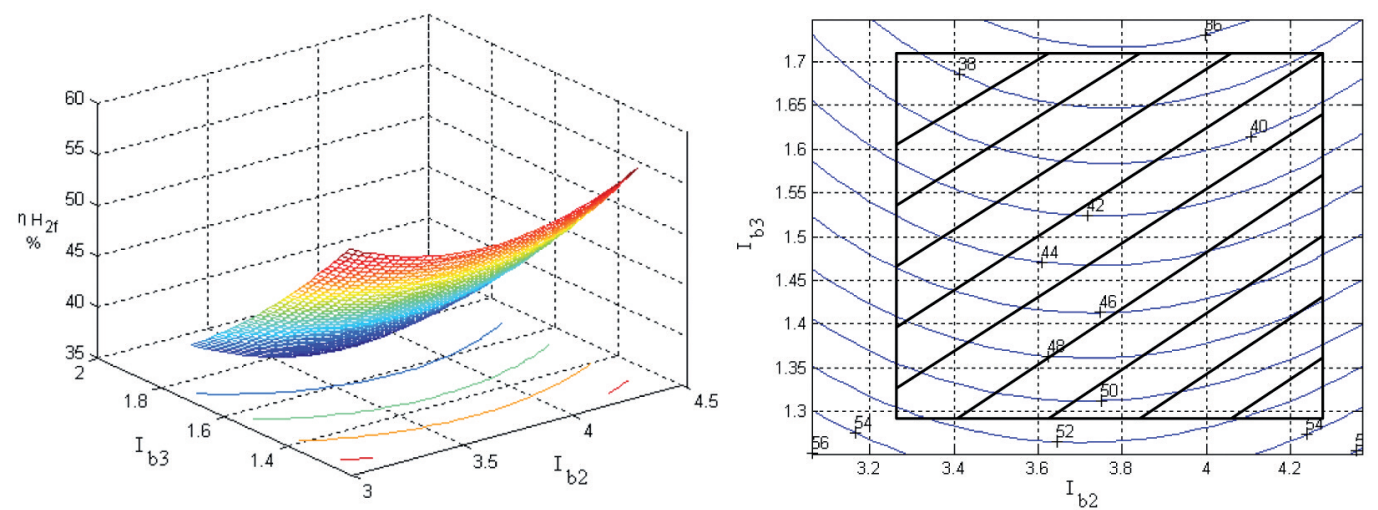

Figure 8. Hydrogen removal efficiency, variant $B, \eta_{f-H-B}$ depending on $\left(I_{b 3}\right)_{\text {med }}, I_{b 2}$ and $\mathrm{I}_{\mathrm{b} 1}$

Figura 8. Eficacia de la eficiencia del hidrógeno, la variante $B, \eta_{f-H-B}$ en función de $\left(I_{b 3}\right)_{\text {med }}, I_{b 2} y I_{b 1}$

In figures 3, 4 and 5 the dependences of the hydrogen removal efficiency depending on $\mathrm{I}_{\mathrm{b} 1}, \mathrm{I}_{\mathrm{b} 2}$ and $\mathrm{I}_{\mathrm{b} 3}$ (through permutations) for variant $\mathrm{A}$ are presented. Analyzing the values of the level curves it results that to obtain the hydrogen removal efficiency higher than $50 \%$, the values for $\mathrm{I}_{\mathrm{b} 2}$ and $\mathrm{I}_{\mathrm{b} 3}$ must be situated in the shaded area (Fig. 3) ( $\mathrm{I}_{\mathrm{b} 2}$ between $3.7-5.4$ and $\mathrm{I}_{\mathrm{b} 3}$ between $1.50-1.75$ ); the values for $\mathrm{I}_{\mathrm{b} 1}$ and $\mathrm{I}_{\mathrm{b} 3}$ must be situated in the shaded area, figure $4\left(\mathrm{I}_{\mathrm{b} 1}\right.$ between $3.1-4.4$ and $\mathrm{I}_{\mathrm{b} 3}$ between $1.50-1.71$ ) and the values for $\mathrm{I}_{\mathrm{b} 1}$ and $\mathrm{I}_{\mathrm{b} 2}$ (Fig. 5) must be situated in the shaded area $\left(\mathrm{I}_{\mathrm{b} 2}\right.$ between $3.65-5.40$ and $\mathrm{I}_{\mathrm{b} 1}$ between 3.25-3.85).

The same type of dependences (graphical and analytical) were obtained for the $\mathrm{B}$ variant of experiments, the results being presented in figures $6-8$. Analyzing the values of the level curves it comes out that to obtain the hydrogen removal efficiency higher that $40 \%$,the values for $\mathrm{I}_{\mathrm{b} 2}$ and $\mathrm{I}_{\mathrm{b} 3}$ (Fig. 6) must be situated in the shaded area $\left(\mathrm{I}_{\mathrm{b} 2}\right.$ between $3.05-4.35$ and $\mathrm{I}_{\mathrm{b} 3}$ between $1.25-1.73$ ); the values for $\mathrm{I}_{\mathrm{b} 1}$ and $\mathrm{I}_{\mathrm{b} 3}$ must be situated in the shaded area $\left(\mathrm{I}_{\mathrm{b} 1}\right.$ between $2.50-3.85$ and $\mathrm{I}_{\mathrm{b} 3}$ between $\left.1.25-1.63\right)$, for figure 7 and respectively the values for $\mathrm{I}_{\mathrm{b} 1}$ and $\mathrm{I}_{\mathrm{b} 2}$ must be situated in the shaded area $\left(\mathrm{I}_{\mathrm{b} 1}\right.$ between $2.50-3.85$ and $\mathrm{I}_{\mathrm{b} 2}$ between 3.1 - 4.4), figure 8 .

The degree of removal of hydrogen obtained from the research is within the range obtained by other steel producers working ${ }^{[9-11]}$ in EBT-LF duplex system. By refining the steel to obtain important 
metallurgical effects of which can be mentioned: degassing, thermal and chemical mixing, non-metallic inclusions flotation, refining accelerating reactions (desulphurization, deoxidation) to melt metal. Achievement of these effects is dependent on the method used and how they are correlated with the main technological parameters of the process purpose.

\section{CONCLUSIONS}

Analyzing the results obtained in the industrial experimentations and the processing of the dates it results that:

- To obtain superior values for hydrogen removal efficiency it is indicated to work with burnt additions and if possible and the supply with lime and dolomite freshly burnt which assures an increase of the efficiency with at least $10 \%$.

- For the working version with burnt additions the variation of the parameters in the limits of $\mathrm{I}_{\mathrm{b} 1}=3.25-3.85, \mathrm{I}_{\mathrm{b} 2}=3.7-5.4, \mathrm{I}_{\mathrm{b} 3}=1.50-1.75$ which assures obtaining an efficiency of minimum $50 \%$.

- Where they don't work with freshly burnt materials or poorly burnt (it's desirable that there are no situations like that) a higher than $40 \%$ level of hydrogen removal efficiency can be obtained if the parameters vary like that $\mathrm{I}_{\mathrm{b} 1}=2.50-3.85$, $\mathrm{I}_{\mathrm{b} 2}=3.10-4.35, \mathrm{I}_{\mathrm{b} 3}=1.25-1.63$.

- Towards the end of processing the steel in the ladle a reduction of the basicity of the slag is made, respectively the shifting of the values $\mathrm{I}_{\mathrm{b} 1}, \mathrm{I}_{\mathrm{b} 2}, \mathrm{I}_{\mathrm{b} 3}$ towards the lower limits of the variation fields to reduce the transfer of the oxygen from the atmosphere in the steel bath during the ladle transport from the LF to TC and during the continuous cast.

\section{Acknowledgment}

This work was partially supported by the strategic grant POSDRU 2009 project ID 50783 of the Ministry of Labour, Family and Social Protection, Romania, co-financed by the European Social Fund - Investing in People.

This work was partially supported by the strategic grant POSDRU/21/1.5/G/13798, inside POSDRU Romania 2007 - 2013, co-financed by the European Social Fund - Investing in People.

\section{REFERENCES}

[1] A. Socalici, E. Ardelean, M. Ardelean, T. Heput and A. Josan, Turnarea i solidificarea o elului, Ed. Cermi, Iasi, Romania, 2007, pp. 32-33.

[2] P. Gómez, F. Reyes, J. Gutiérrez and G. Plasencia, Rev. Metal. Madrid 45(2009) 305-316.

[3] I. Butnariu and V. Geant, Tehnologii speciale de elaborare $i$ rafinare a o elurilor, Ed. UPB, Bucuresti, 1993.

[4] G. Nica, A. Socalici, E. Ardelean and T. Hepu, Tehnologii pentru îmbun $t$ irea calit ii o elului, Ed. Mirton, Timisoara, Romania, 2003, pp. 48-52.

[5] J. Plessis, Thesis Doctoral, Faculty of Engineering, University of Pretoria, 2006.

[6] T. Hepu, E. Ardelean and I. Kiss, Rev. Metal. Madrid 41(2005) 220-226.

[7] S. Maksay and D. Bistrian, Introducere in metoda elementelor finite, Ed. Cermi, Iasi, Romania, 2008, pp.157-158.

[8] K. N. Jha, M. K. Sardar, N. N. Jha and S. Chakraborty, Scandinavian Journal of Metallurgy, 32 (2003) pp. 296-300.

[9] J. Brandberg, Licentiate Thesis, Royal Institute of Technology, Stckholm, Sweden, 2006.

[10] R.J. Fruehan, The Making, Shaping and Treating of Steel. 11th Edition Steelmaking and Refining Volume Pittsburgh, USA, AISE Steel Foundation. 2003. 